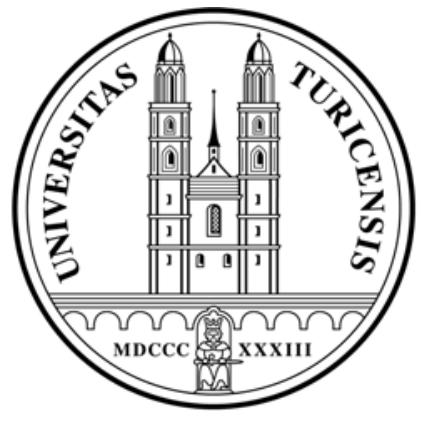

Institute for Empirical Research in Economics

University of Zurich

Working Paper Series

ISSN 1424-0459

Published in:

International Journal of the Economics of Business, 11(2), pp. 141-163. (2004)

Working Paper No. 148

DO BUSINESS STUDENTS MAKE GOOD CITIZENS?

Stephan Meier and Bruno S. Frey

May 2003 


\title{
DO BUSINESS STUDENTS MAKE GOOD CITIZENS?
}

\author{
STEPHAN MEIER \\ University of Zurich \\ BRUNO S. FREY \\ University of Zurich
}

Institute for Empirical Research in Economics

Bluemlisalpstr. 10, 8006 Zurich, Switzerland

Phone: +41-1- 63437 30/31, Fax: +41-1-634 4907

e-mail: smeier@iew.unizh.ch,bsfrey@iew.unizh.ch

(June 30, 2002) 


\title{
DO BUSINESS STUDENTS MAKE GOOD CITIZENS?
}

\begin{abstract}
:
Business students are portrayed as behaving too egoistically. The critics call for more social responsibility and good citizenship behavior on the part of business students. We present evidence of pro-social behavior in business students. Every student at the University of Zurich has to decide each semester whether he/she wants to contribute to two social funds administrated by the University. With this large panel data set, we can analyze whether business students indeed behave less pro-socially than other students. Two specific hypotheses are tested: do students select into business studies or does the training in business studies indoctrinate students in a negative way? The evidence suggests that there may be a selection effect going on. Therefore, business education does not change the citizenship behavior of business students. (136 words)
\end{abstract}

Reviewer Topic Codes: Management Education (2), Social Issues in Management (9), Individual differences $(3 a)$ 
This paper looks at the pro-social behavior of business students and how education influences their behavior with respect to engaging in charitable donations. Pro-social behavior (PSB) is related to organizational citizenship behavior (OCB) and includes all contributions to a common good (e.g. voluntary work, helping needy people, making donations and protecting the environment). Business students are often seen to behave more selfishly than the rest of the population. Already in 1966, based on a questionnaire, a sociologist deduced that "...business students are more concerned strictly with maximizing their own welfare, disregarding the other's ..." (Sawyer, 1966: 414). This result was further supported by studying behavior in experiments for economists: they tend to donate less money, cooperate less in social dilemma situations and give less money in dictator games (e.g. Marwell and Ames, 1981; Carter and Irons, 1991; Cadsby and Maynes, 1998). Moreover, some scholars claim that the behavioral differences between business students and non-economists are due to economics education (Frank, Gilovich et al., 1993; 1996). This would mean that training in business administration negatively affects the PSB of students.

Previous research on this topic was mainly based on survey studies or laboratory experiments with students as subjects. But one cannot exclude that the students see their participation in survey studies and experiments as an 'IQ test of sorts' (Frank, 1988: 228) and play the equilibrium they learned in class, when they wouldn't do this in a real life situation. In contrast, we use a natural decision setting at the University of Zurich to explore the pro-social behavior of business students. At the University of Zurich, in the first four semesters, students study both business administration and economics. Only after two years they separate into business and economics education. We find that business students behave less pro-socially than other students. However, the behavioral differences are not due to business education, but to a selection effect. Already at the beginning of their studies, business students contribute less than non-economists. Our results suggest that business training does not lower cooperation and pro-social behavior. 
The paper proceeds as follows: Section I presents the hypotheses and previous research. Section II presents the data set. The empirical results are discussed in section III, which also dicusses alternative hypotheses. A final section draws conclusions.

\section{HYPOTHESES AND PREVIOUS RESEARCH}

\section{Theoretical considerations}

Contributions to public goods are an important part of everyday life. Without cooperative and helpful behavior, firms and society as a whole could not function. Standard economic theory assumes that people are selfish and therefore predicts that they neither contribute sufficiently to a pure public good, nor do they cooperate in a social dilemma situation, due to the incentive structure. But empirical evidence shows that a substantial number of individuals do behave pro-socially. A large literature is devoted to analyzing the factors that drive pro-social behavior in general or in organizations. ${ }^{\mathrm{i}}$ There are, however, many studies which claim that business students show less cooperative and ethical behavior than other people, keeping everything else constant. Daboub et al. (1995: 156), for example, express the proposition that "[...] corporate illegal activity will be stronger for firms whose TMT's [Top Management Team] have a greater amount of formal management education (i.e., a greater percentage of MBAs)." However, if one really observes behavioral differences between business students and other people, e.g. students of other disciplines who differ from business students only in their education, such differences could be attributed to two effects:

Hypothesis 1 (Selection hypothesis): Less pro-social persons choose to study business administration. We would expect differences in the behavior of business students and other students to be present at the onset of their studies, without ever having attended a single lecture in economic theory.

This hypothesis is based on the notion that people differ in their pro-social preferences. With respect to their 'social value orientation' people may be divided, for example, into individualistic, competitive 
and cooperative types (Messick and McClintock, 1968; McClintock, 1978). ${ }^{\text {ii }}$ According to this hypothesis, 'selfish' types self-select into business schools and the observed behavioral differences are due to this selection process and not to any effect of business education. However, there may be another explanation for behavioral differences between business students and other students, which has more serious implications for business education:

Hypothesis 2 (Indoctrination hypothesis): Business students are indoctrinated by training in management and economics theory. We would expect that behavioral difference between business students and others increase during the studies. In other words, the more business students learn the theory, the more selfishly they behave - compared to other students.

Students may, for example, take the expected utility theory (Von Neumann and Morgenstern, 1947), which is common in business education, as normative advice for their own behavior (Jones et al., 1990). Due to their game theoretical education, business students reduce their expectations about the pro-social behavior of others. This would also lead to a reduction in their own pro-social behavior, according to theories of social comparison and reciprocity (e.g. Kelley and Stahelski, 1970; Fischbacher et al., 2001; Frey and Meier 2003b). But, more generally speaking, the business education decreases cooperative behavior because the training "(a) teaches a language devoid of ethical symbols, (b) provides a set of simplified assumptions about how the world works, and (c) reinforces acceptance of the rational/economic world view" (Daboub et al., 1995: 155). If Hypothesis 2 proves valid, business schools would educate their students to the type of selfish persons they axiomatically assume in their theories.

The two hypotheses are not mutually exclusive and have to be tested empirically. 


\section{Previous research}

There are three ways of addressing the question of whether business education makes students less prosocial: (1) asking questions about students' attitudes, (2) analyzing their behavior in laboratory experiments, and (3) looking at real-life behavior.

(1) Already Sawyer (1966) finds substantial differences between the attitudes of business students and other students. Others, like e.g. Schein (1967), test the extent to which attitudes change with management education. His results do not show that students change their 'General Cynicism' between the beginning and the end of their studies. Later studies, which are more interested in the impact of ethics courses, found that "the decisions made by business students were significantly less ethical [...]" than law students (McCabe et al., 1991: 955). A follow-up study shows that business students hardly change their ethical attitudes, whether they took an ethics course or not ( McCabe et al., 1994). Similar results are found by Gandal and Roccas (Gandal and Roccas, 2000), who analyze the values held by economists and non-economists. They identify differences in the value priorities reported by students of economics compared to non-economists. But these differences already emerge before any economics indoctrination can take place. Problems with such studies may of course be that telling the truth is of no benefit. Business students may express their perceived appropriate behavior, while in reality they would have behaved in a totally different way.

(2) Taking into account some of the shortcomings of surveys, most studies in economics use laboratory experiments to analyze behavioral differences. Students play, for example, a prisoner's dilemma game and earn the respective amount of money. In such settings, material incentives exist to behave 'selfishly'. In this academic community, the results of Frank, Gilovich and Regan $(1993 ; 1996)$ that economics education has a negative influence on students' cooperative behavior (i.e. that there is an indoctrination effect of economics) is widely accepted. But the literature on the topic is less uniform than suggested by Frank et al. (1996: 192), who argue that there is: ' ... a heavy burden of proof on those who insist that economics training does not inhibit cooperation.' While Carter and Iron 
(1991:174) find that "economists are born, not made", there are many more experimental studies which do not find a negative effect of economics education on cooperative behavior (Marwell and Ames (1981); Frey, Pommerehne and Gygi (1993); Bohnet und Frey (1995); Seguino, Steven and Lutz (1996); Cadsby and Maynes (1998); Stanley and Tran (1998); Frank and Schulze (2000)). Laboratory experiments, however, have their shortcomings. If economists make economic experiments with other economists to see whether they behave like economists, one shouldn't be surprised if they really do so. (3) Only three of the previous studies on this topic go beyond laboratory experiments. One of them is a "lost letter" experiment by Yezer et al. (1996), where envelopes containing money are dropped in different class rooms. On the basis of the number of letters returned, the study concludes that economists are even more honest than students of other subjects. However, the authors cannot control for personal characteristics (e.g. gender and age) as they do not know who picks up the envelope. A second paper, looking at 'real world' behavior, is that of Laband and Beil (1999). They consider the differences in the professional associations' dues payment, which are income-based. However, income is self-reported (hence, the correct amount cannot be enforced). With that in mind, the authors undertake a survey of the members" "true" income and find that sociologists are more likely to cheat than either economists or political scientists. If the 'monetary' incentives for cheating (owing to different dues) are taken into account, the authors believe that there are no significant differences between professional academics. But there again, this study does not control for personal characteristics. Business students may differ from other students in their composition according to e.g. gender. When women behave more pro-socially, we would not observe an effect of business education but of gender composition. In addition, the setting in the two studies mentioned does not allow for discrimination between the two hypotheses. Frey and Meier (2003a) show in their study on giving behavior in a real-life situation that economics students do not behave more selfishly than students of other faculties. They, however, concentrate on economics students instead of business students. 
To sum up, the evidence about the effect of business education on students' behavior is mixed. Most studies are restricted to survey evidence or laboratory experiments, both of which have their shortcomings. Most previous studies concentrate on the behavior of economists and do not show the effects for business students. With the data set used in this paper, the question of whether business students behave selfishly can be addressed in a natural setting. The behavior of business students can then be compared to that of economics students. As both selection and indoctrination may be at work, it is useful to discriminate between the two hypotheses. The data set used allows us to address both hypotheses simultaneously.

\section{THE DATA SET}

All of the students at the University of Zurich are asked each semester by the University administration whether they want to contribute to two official funds - in addition to the compulsory tuition fee. Before the semester starts, the students must decide, based on an official letter, whether they want to donate money to needy students (CHF 7.-, about US\$ 4.20), who then can receive a free loan from one of the funds (Loan Fund) and/or if they want to donate money to foreign students (CHF 5.-, about US\$ 3), who can receive money in order to study for one or two semesters in Zurich (Foreigner Fund). By ticking the respective box, students consent to pay into the funds. We observe the decisions for the period from the winter semester 1998/99 up to and including the winter semester 2002/03 (i.e. nine semesters). The fact that every student has to decide each semester whether to contribute or not leads to a large number of observations. We can observe the giving behavior of 37,588 students, who decide on average 4.8 times, depending on how many semesters they have attended. The decisions of the nine periods are pooled, which generates 180,225 observations. With this panel data set, it is possible to test whether training in economic theory really erodes the willingness to cooperate or, more generally, civic virtue and trust. 
The way the study of economics is organized at the University of Zurich allows us to control for different levels of economic knowledge. Initially, students undertake their basic study, which lasts about 2 years ( 4 semesters). After passing an exam covering basic business administration theory and macro- and microeconomics, they enter the main stage of their study and choose between business administration and economics. After graduating, students may start their Ph.D. study. Some of the students get basic economics knowledge in high school. We control for this pre-university knowledge (in economics).

In addition, an anonymous on-line survey was undertaken among the same student group of the University of Zurich. ${ }^{\text {iii }}$ The response rate was 18 percent. From this sample, we were able to use 3'256 answers, containing responses to all the questions relevant for our context. This sample is not totally representative (not surprisingly, a larger number of economics students responded to the questionnaire sent out by two economists), but with respect to gender and age, the sample corresponds to the distribution of students at the University of Zurich. See table 1 for summary statistics of the survey data set. The survey again asked whether the person contributed money to one or both of the funds. 73 percent responded that they did, compared to the 68 percent who actually contributed. This difference between survey answers and actual behavior is found in a lot of survey-based studies. While the differences can be the result of people lying (see Eichenberger and Oberholzer-Gee (1998) and Bertrand and Mullainathan (2001) for differences between hypothetical and real decisions), a more convincing explanation is that people who actually contributed to the Funds are more likely to respond to the online survey. The differences should be kept in mind when interpreting the survey data. The dataset analyzed in this study has three clear advantages compared to most other studies:

(1) We observe behavior in a naturally occurring situation. However, the amount of money at stake seems to be small. But, for at least some of the students the contributions represents a substantial amount of the money they have at their disposal. Moreover, the contributions to the 
two funds serve as a proxy for more general PSB. In the online survey, we asked people whether they donate money to other funds (apart from the two social funds) and whether they volunteer. People who contribute to at least one of the two funds are statistically significantly more likely to donate to other funds. $56.5 \%$ of people who contribute to the funds also donate to other funds, versus $48.7 \%$ who don't $(\mathrm{t}=3.56 ; \mathrm{p}<0.001)$. And students who contribute to the two funds, donate more money: on average CHF 259.5 (s.d.=14.4) vs. $197.6($ s.d.=27.3) $(\mathrm{t}=1.87$; $\mathrm{p}<0.06$ ). Where volunteering is concerned, the stituation is less clear. Students who donate to the two funds volunteer more, but the difference is not statistically significant. However, one can see that the contributions to the two social funds can indeed act as some sort of proxy for more general PSB.

(2) The decision setting is clear and anonymous. Characteristics not connected to business education, and which may influence giving behavior, are controlled for. The anonymous situation allows us to exclude motives such as prestige (e.g. Harbaugh, 1998) or social pressure (Ostrom, 1998).

(3) We observe the behavior of a large number of students. This allows us to compare the behavior of business students to students of other disciplines, in particular to economists. 


\section{EMPIRICAL RESULTS}

The first subsection looks at the raw data, followed by an in-depth analysis of the selection hypothesis and the indoctrination hypothesis. In the following subsection, alternative hypotheses will be tested using data from the survey.

\section{Descriptive analysis}

Table 1 shows the summary statistics of the data set. Only about $10 \%$ of the university students are economists in the broad sense (business and economics students together). This allows us to compare their behavior with a large range of students of other subjects. And, as can be seen from table 1, most of the economists study business administration.

\section{TABLE 1 ABOUT HERE.}

The raw data clearly show the differences between business economists and non-economists. Table 2 shows the descriptive statistics for the giving of economists and non-economists who contribute to at least one fund. Throughout the analysis, we concentrate on the minimal contributions ('to at least one of the funds'). The results do not change when we look at all four options (Loan Fund, Foreigner Fund, both funds or neither of the funds).

\section{TABLE 2 ABOUT HERE.}

Overall, $64.5 \%$ of the economists (business and econ students) contribute to at least one fund, compared to $70.2 \%$ of the non-economists. This difference is highly statistically significant (t-test: $\mathrm{t}=16.20, \mathrm{p}<0.001)$. This result supports the notion that there are differences in pro-social behavior (PSB) between economists and non-economists, and that the differences are quite big. To further detect whether these differences are due to a selection or an indoctrination effect, we have to look at the beginning of the students' career at the University of Zurich and how PSB develops throughout their studies. With respect to these questions, table 2 shows three interesting patterns: 
(1) A big difference already exists at the very beginning of the University study. Freshmen, before attending a single lecture, differ in a statistically significant way in their behavior. $74.5 \%$ of noneconomists contribute, compared to only $70.7 \%$ of the economists $(t=3.35, p<0.001)$. This result seems to support the selection hypothesis.

(2) During the main stage of their study, the willingness to contribute decreases dramatically for business students. Only $57 \%$ contribute to the funds, while $72 \%$ of the non-economists behave prosocially. The difference of 14 percentage points is statistically significant $(\mathrm{t}=23.64, \mathrm{p}<0.001)$. The difference widens, thus supporting the indoctrination hypothesis. For economists on the other hand, PSB changes in the same way as for non-economists. For political economists, no indoctrination effect is to expected based on the descriptive analysis.

(3) During their Ph.D. studies, the differences between business students and non-economists level off. $62.4 \%$ of business economists donate money in this stage of their studies, compared to $62 \%$ of noneconomists. However, the difference is not statistically significant at a conventional level $(\mathrm{t}=1.27$, $\mathrm{p}<0.20$ ). For business students, this signifies an increase in PSB. For non-economists, we observe a respective decrease. This pattern does not fit the indoctrination hypothesis: If a possible indoctrination effect increases according to the number of semesters studied, one would expect Ph.D. students to be most affected.

The descriptive analysis clearly supports the selection hypothesis, while showing an unclear picture concerning the indoctrination hypothesis. However, business students and students of other subjects may of course differ in other respects. This can influence PSB besides business and economics training. For example, women in Zurich are less likely to choose to study business and economics studies than other subjects (e.g. humanities). A 'business education' rather than a 'gender' effect may result. ${ }^{\text {iv }}$ To exclude such alternative interpretations, the next sections control for such factors, using multiple 
regression analysis. First the selection effect is analyzed in detail and then the indoctrination effect is studied, using methods to control for personal heterogeneity.

\section{Selection hypothesis}

In order to test whether individuals who choose to study business and economics behave less prosocially, we take a closer look at the first decision to contribute to the two funds. Table 3 presents a probit analysis, which controls for personal characteristics. The dichotomous dependent variable equals 1 if the student contributed to at least one of the two funds and 0 if the students free-ride completely. Because some students acquired economics knowledge in high school, we control for this effect by the dummy variable pre-university knowledge, which equals 1 if the students had economics in their high school curriculum and 0 otherwise. We also control for personal characteristics: the dummy variable gender equals 1 for women, nationality is 1 for foreigners and 0 for Swiss citizens and age is controlled for. As this is a pooled data set, we control for the time when the decision was taken by including time dummies. Because the coefficients in a probit analysis are not easy to interpret, marginal effects are computed. They show how the probability of contributing changes compared to the reference group.

\section{TABLE 3 ABOUT HERE.}

The results support the selection hypothesis. The probability that a business or econ student contributes to one of the funds is 4.4 percentage points lower compared to the reference group of non-economists. The effect is statistically significant at a $99 \%$-level. Thus, before attending a single lecture in business management or economics, business and econ students contribute less than other students do in their first semester. We can exclude the possibility that pre-university knowledge is responsible for the observed behavioral difference. However, pre-university knowledge in economics has an effect on contributions. The probability of contributing is 2.9 percentage points lower if students acquired economics knowledge in high school. This effect can either be a selection or an indoctrination effect, but it cannot explain the selection effect into the business and economics study. The control variables 
reveal the following information: women are less likely to contribute to the funds at this stage of their study. Foreigners do not show any difference with respect to pro-social behavior at this stage of the study. As will be seen later, however, they are overall less prepared to act pro-socially. While the effect for women is statistically significant, it is not the case for foreigners. The effect of age is in line with other studies about giving behavior (see for an overview, Andreoni, 2002): the older the students are, the more they behave in a pro-social way or contribute to the two funds. ${ }^{\mathrm{v}}$

At the University of Zurich, students have to attend approximately two years of basic studies in business administration and economics. After that, they specialize in business or economics. Therefore, it is impossible to know whether the less pro-social students select business administration or economics. But, as we have a panel data set, we can observe how students, who later chose one or the other of the two subjects, behaved in their first semester or in their basic study. Table 4 shows the respective number of business and economics students who contributed to one of the two funds in either their first semester or the basic study. The descriptive statistic is already striking: business students behave significantly less pro-socially than economics students do. Only $60 \%$ of business students contribute when making their first decision, compared to $77 \%$ of economics students in their first semester. In the basic study as a whole, the differences remain almost as impressive: $65 \%$ of business students contribute to at least one fund, compared to $74 \%$ of economics students. Both differences are at least statistically significant at the 95\%-level. Therefore, less pro-social students tend to choose business administration. However, business administration is not the only subject which attracts individuals who are less prepared to contribute. ${ }^{\text {vi }}$

TABLE 4 ABOUT HERE.

To sum up, the results show that the behavioral differences can be explained by a selection effect. In their first semester, business students contribute substantially less than non-economists do. However, the indoctrination hypothesis also has to be tested because the hypotheses are not mutually exclusive. 
In the next section, we will therefore analyze if the evolution of behavioral differences between business students and non-economists is (also) due to their education in business economics.

\section{Indoctrination hypothesis}

Does training in business studies have a negative effect on business students' cooperative behavior? It may be conjectured that the more the students learn about the maximization of firms' profits, the more they personally act in a profit maximizing way. For those students not confronted with business and economics theory in every lecture, such a decline should not take place. If the differences in giving behavior between business students and students of other disciplines increase with every additional semester, the indoctrination hypothesis is not rejected. Table 2 reveals an ambiguous picture. While the contribution from the basic stage to the main stage shows more of a decrease for business students than for non-economists (and economics students) - which would support the indoctrination hypothesis (business and econ) students contribute more than non-economists in the Ph.D. stage. If indoctrination really influences the behavior of students, the effect should - ceteris paribus - be most obvious at the doctoral level, where the students have absorbed the largest amount of economics training. But to test the indoctrination effect properly, two things have to be borne in mind. Firstly, business students can also differ from non-economists because of other factors influencing giving behavior (e.g. gender or age). We therefore control for such effects by way of a multivariable probit regression. Secondly, students in different stages of their studies can differ from each other in unobservable characteristics. Some do not pass the exams after the basic studies, making students in the main stage or the Ph.D. stage a special selection. It seems obvious that Ph.D. students may be an even more special selection and therefore hard to compare with general business students. With a conditional logit estimation including personal fixed-effects, we can control for such unobserved personal characteristics and exclude individual heterogeneity. The two models are presented in table 5. 
TABLE 5 ABOUT HERE.

Model I in table 5 presents the probit estimation. The dichotomous dependent variable equals 1 if students contribute to at least one fund and 0 otherwise. The variable Business and Economics Students in the estimation again supports the selection hypothesis: business and economics students contribute less to the funds - independent of the stage of study. The probability is $3.2 \%$ lower than for noneconomists. ${ }^{\text {vii }}$ Model I supports the inconsistent picture with respect to the indoctrination effect for business students: moving from the basic stage to the main stage of university education raises students' PSB by 4 percentage points. The coefficient of the dummy for Main Stage*Business Students measures the differences between business students and non-economists when entering the main stage, and hence serves as a test for the indoctrination effect. For business students, entering the main stage of their studies lowers the probability of PSB by about 8 percentage points - in addition to the general effect for entering the main stage. This effect is statistically significant. In comparison, the probability of PSB even increases for economics students, and is statistically significant at a $95 \%$-significance level. The results for business students does not necessarily indicate the impact of indoctrination, because the probability of PSB increases for doctoral students. The probability for business students increases about 6 percentage points, which is statistically significant at a 99\%-level. As mentioned already, one would expect indoctrination to be most marked in the Ph.D. stage, where students have accumulated the largest amount of economics training. The argument that indoctrination should be highest in the Ph.D. stage assumes, however, that doctoral students differ from other students only in the stage of the studies. But Ph.D. students are maybe a different selection of people, which also has to be taken into account.

The results and interpretation of the indoctrination effect presented above are problematic in one respect: as already mentioned for $\mathrm{Ph}$. D. students, students in the main stage of their studies can be seen as a particular selection of people compared to students in the basic stage, because a large number of students fail to pass the exam enabling them to enter the main stage. Thus, a sample selection bias 
cannot be excluded. To eliminate these doubts, we use the panel structure of the data set and test the indoctrination effect in a conditional logit model with personal fixed effects (e.g. Greene, 1997: 612647). With this method, we can exclude any selection biases by holding unobserved personal characteristics constant.

Model II in table 5 presents the results of the conditional fixed effect logit model. In this type of model, because only those students are of interest who have at least once changed their pattern of decision making with respect to contributing to the funds, the sample is reduced to 12,035 persons. These students decided on average 6.2 times, which leads to 74,982 observations. The model used allows us to make intrapersonal comparisons. It looks at how individuals change their behavior when e.g. entering the main stage. Of course, variables, which do not change during the course of their studies, like pre-university knowledge, gender or nationality, have to be excluded from the analysis. The results do not support the indoctrination hypothesis. Neither of the two coefficients, which would measure the effect of business and economics training on PSB, shows a statistically significant effect. The coefficient of Main Stage*Business Students and of Ph.D. *Business Economists even have the wrong sign. In Table A.1 in the Appendix, we replicated the results for different measurements of a potential indoctrination effect, e.g. whether PSB decreases with the number of semesters in business administration. These estimates also show that, when unobserved heterogeneity is not controlled for, the indoctrination hypothesis cannot be falsified. However, the results of the models with personal fixed-effects, which only look at intrapersonal differences, reveal another picture: business education does not have a negative effect on students' willingness to contribute money to the two social funds. The intuition behind this finding can be shown if we look at the aggregate behavior of people, who we observe in the basic and in the main study. It can then be observed whether this group of people changes its actual behavior. The evidence for business students is very clear. $64.9 \%(\mathrm{~N}=2150)$ contribute in the basic stage while $67.8 \%(\mathrm{~N}=1915)$ do so in the main stage. The slight increase in PSB 
is statistically significant $(\mathrm{t}=1.955 ; \mathrm{p}<0.051)$. This again shows that business students do not change their behavior when entering the main stage.

The data do not support a negative effect of economics education on PSB. When we control for possible selection biases, we do not find an indoctrination effect. The effects of the probit model in table 5 are due to unobserved heterogeneity. Students in the main stage differ from students in the basic or the Ph.D. stage in unobserved personal characteristics. Business students therefore do not see economic theory as a normative advice for pro-social behavior.

\section{Discussion of Alternative Hypotheses}

Three alternative hypothesis will be discussed in this section: (1) business students differ in other dimensions from non-economists (e.g. income), which may explain the differences observed; (2) other factors such as peer pressure can explain giving behavior and maybe differences between business students and others; and (3) business students focus more on the 'efficiency' of fund management and may not contribute because of that.

Evidence from the online survey of the student population allows us to address the three alternative hypotheses:

(1) Income situation. Economists' income may differ from students of other subjects. This may explain the behavioral differences. The survey allows us to determine the income situation, assuming that the better off a student is, the more likely he or she is to help others. This hypothesis is based on empirical research that the percentage of households who donate increases with income, while the percentage of household income devoted to giving to charity is related to income in a u-shaped way (e.g. Andreoni, 2002: 11372). Those students working to help finance their studies (which is a significant number of students at the University of Zurich) are expected to donate less. In a recent study, students decreased their contribution in a dictator game substantially when they had to earn the money, compared to a 
situation where they received the money from the experimenter (Cherry et al., 2002). In contrast, when parents pay for their studies (and therefore the contribution to the funds), it is likely that students are more generous with respect to their fellow students. Thus a classical low-cost decision situation may occur (e.g. Kirchgässner, 1992).

Model I in table 6 presents the probit estimates, again controlling for age, gender and the number of semesters attended.

\section{TABLE 6 ABOUT HERE.}

The survey results replicate the results of the analysis of the real data. Students of business administration give significantly less when they enter the main stage of their studies. The results also hold when controlling for the income situation, which can be seen in Model II in table 6, where income variables are added.

The results on income are not surprising. As expected, income has a strong positive effect on the probability to contribute to the two funds. The more a student finances his own living, the less he or she is willing to contribute. The fact that parents pay the fees does not, in a statistically significant way, change the probability of one's own decision to donate. The variables used as controls are not extremely stable, but do have the expected signs. The tested determinants of giving behavior are, however, not responsible for the differences between economists and non-economists.

(2) Other factors influencing PSB. Other factors may influence the PSB of students such as peer pressure or family background. It is certainly true that giving behavior is influenced by many variables, which are not explicitly controlled for. However, the data set presented allows us to exclude these factors as being irrelevant. First of all, the decision setting is completely anonymous. This leaves little room for motives like prestige or peer pressure. However, it could be that business students talk more about monetary issues like donating money. The survey results show that business students indeed talk significantly more with others about the funds. $30 \%$ of business students compared to $23 \%$ of others talk with each other about the funds $(\mathrm{t}=2.31 ; \mathrm{p}<0.02)$. It is, however, completely unclear how the 
conversation between students would influence the PSB. In various studies, conversation between people leads to more cooperation in social dilemma situations (Sally, 1995), suggesting that conversation leads to increased contributions. Because business students talk more with each other about the funds, they should contribute more, not less. If conversation is controlled for in an analysis analogue to table 6 , the effect of being business students does not vanish.

(3) Awareness of efficient management. Business students may evaluate the funds' management efficiency to a greater extent than would other students. With more business education, this may be more extreme. A lower contribution rate may therefore be due to a higher awareness of the shortcomings of the specialized funds. Business students become more skeptical about the effectiveness of the funds with more business education. They also increasingly substitute these particular funds with other charities. In the online survey, we asked the students 'how do you evaluate the effectiveness of the funds?' on a scale from $8=$ 'good' to $1=$ 'bad' (with a 'no idea' option).

\section{TABLE 7 ABOUT HERE.}

Table 7 shows that business and economics students indeed evaluate the funds in a much more critical way than others. Taking the 'no idea' answers into account, the mean for business and econ students is 4.87 compared to 5.27 for others $(t=3.37 ; \mathrm{p}<0.01)$. The perceived efficiency decreases slightly for business and economics students in the basic and in the main stage of their study. However, this decline is not statistically significant at any conventional level $(\mathrm{t}=0.598 ; \mathrm{p}<0.550)$. This supports the selection hypothesis, claiming that business students differ from others already at the beginning of their studies. During their studies, students do not change their attitudes much. This conclusion can be supported by analyzing answers to other questions in the same way, for instance the perceived importance of funds, expectation about others' behavior or political orientation. Business students are a special selection of people and education does not change these attitudes. The limitation of the survey is that we cannot distinguish between business and economics students in the basic study, so the evidence presented holds only for the two groups taken together. If the alternative hypothesis was true, one should expect 
that business students substitute for other charitable funds during their studies. The survey results indicate that donating to other funds cannot explain the giving behavior to the two social funds. Business and economics students do not increase their donation to charities outside of the University in a statistically significant way.

To sum up, the three alternative hypotheses cannot explain differences in PSB to the two social funds at the University of Zurich. Differences in material resources, other motives such as peer pressure or prestige, and different levels of awareness of efficiency cannot explain the differences in PSB between business students and other students. The evidence presented by the online survey supports the selection hypothesis even further, showing that business students differ right at the beginning of their studies from other students, but business education does not change their behavior afterwards.

\section{CONCLUSIONS}

The analysis of the actual behavior of students with respect to anonymously donating money to a fund as a pure public good allows us to draw three conclusions:

(1) The willingness to behave pro-socially is lower for economists (business and economics students) than for non-economists.

(2) The differences are due to business students who self-select into the subject. Business studies, therefore, attract more people who show less pro-social behavior (PSB).

(3) After controlling for personal heterogeneity, no negative effect of business education could be found. Business students' PSB is not eroded because they learn management theory.

These conclusions are based on the real life behavior of roughly 37,000 students at the University of Zurich. The city of Zurich provides a good example of a students' body in a moderately large city. The education the business students receive is similar to the respective education received elsewhere. As a considerable number of the students are in some kind of employment while studying, they tend to be in close contact with firms and general employment. 
The evidence presented is only one attempt at evaluating the effect of business education on PSB and leaves a lot of room for future research. Firstly, students in our study decide about a relatively small amount of money. Although this correlates with other dimensions of PSB, like donating in general, future studies may look at other behavior, e.g. illegal behavior in firms. Secondly, the differences between business students and students of other subjects are relatively modest, but due to the large number of observations, they are statistically significant. Therefore, it would be interesting to know whether behavioral differences are always that modest or whether in some areas of PSB larger differences emerge. Thirdly, the study took place in Switzerland, so allowance may need to be made for possible cultural differences between Switzerland and other countries with respect to giving behavior or PSB in general.

The conclusions drawn here are important, especially with respect to the recurring demand that business students should be educated to become good citizens. We show that business education does not change the citizenship behavior of business students. Therefore, teachers of business management should be quite comfortable with their subject, knowing they are not to blame for lowering PSB of their students. However, there may still be the possibility that ethics courses increase PSB of business students. But business schools should be aware of the fact that they attract more students with lower than average PSB. 


\section{REFERENCES}

Andreoni, J. \& Vesterlund, L. 2001. Which Is the Fair Sex? Gender Differences in Altruism. Quarterly Journal of Economics, 11: 293-312.

Andreoni, J. 2002. The Economics of Philanthropy. In: N.J. Smelser \& P.B. Baltes (Eds.). International Encyclopedia of the Social and Behavioral Sciences, London: Elsevier.

Bertrand, M. \& Mullainathan, S. 2001. Do People Mean What They Say? Implications for Subjective Survey Data. American Economic Review, 91(2): 67-72.

Bohnet, I. \& Frey, B.S. 1995. Ist Reden Silber und Schweigen Gold? Eine ökonomische Analyse. Zeitschrift für Wirtschafts- und Sozialwissenschaften, 115: 169-209.

Cadsby, C.B. \& Maynes, E. 1998. Choosing Between a Socially Efficient and Free-Riding Equilibrium: Nurses Versus Economics and Business Students. Journal of Economic Behavior and Organization, 37: 183-192.

Carter, J.R. \& Irons, M.D. 1991. Are Economists Different, and If So, Why? Journal of Economic Perspectives, 5 (2): 171-177.

Charness, G. \& Rabin, M. 2002. Social Preferences: Some Simple Tests and a New Model. Quarterly Journal of Economics, 117(3): 817-69.

Cherry, T. L., Frykblom, P. \& Shogren, J. F. 2002. Hardnose the Dictator. American Economic Review, 92(4): 1218-21.

Clotfelter, Ch. T. 1997. The Economics of Giving. In: Barry, J W. \& Manno, B. V. (Eds.). Giving Better, Giving Smarter. Washington, D.C.: National Commission on Philanthropy and Civic Renewal: 31-55.

Daboub, A. J., Rasheed, A. M.A. Priem R. L. \& Gray, D. A. 1995. Top Management Team Characteristics and Corporate Illegal Activities. Academy of Management Review 20(1): 138-70.

Eckel, C. C. \& Grossman, P. J. 1997. Are Woman less Selfish than Men? Evidence from

Dictator Experiments. The Economic Journal 108: 726-35.

Fischbacher, U., Gächter, S. \& Fehr, E. 2001. Are People Conditionally Cooperative?

Evidence from a Public Goods Experiment. Economics Letters 71(3): 397-404.

Frank, B. \& Schulze, G. 2000. Does Economics Make Citizens Corrupt? Journal of Economic Behavior and Organization, 43 (1): 101-113.

Frank, R.H. 1988. Passions with Reason. The Strategic Role of the Emotions. New York: Norton. 
Frank, R.H., Gilovich, T. \& Regan, D.T. 1993. Does Studying Economics Inhibit Cooperation? Journal of Economic Perspectives, 7 (2): 159-171.

Frank, R.H., Gilovich, T.D. \& Regan, D.T. 1996. Do Economists Make Bad Citizens? Journal of Economic Perspectives, 10 (1): 187-192.

Frey, B. S. \& Meier, St. 2003a. Are Political Economists Selfish And Indoctrinated?

Evidence From a Natural Experiment. Economic Inquiry 41(3). 448-462.

Frey, B. S. \& Meier, St. 2003b. Social Comparison and Pro-Social Behavior: Testing 'Conditional Cooperation' in a Field Experiment. Working Paper Series. University of Zurich.

Frey, B.S., Pommerehne, W.W. \& Gygi, B.W. 1993. Economics Indoctrination or Selection? Some Empirical Results. Journal of Economic Education, 24 (3): 271-281.

Gandal, N. \& Roccas, S. 2000. Good Neighors/Bad Citizens: Peronal Value Priorities of Economist. Working Paper Series. Foerder Institue.

Greene, W. H. 1997. Econometric Analysis. Upper Saddle River, NJ: Prentice Hall.

Harbaugh, W. T. 1998. What Do Donations Buy? A Model of Philanthropy Based on

Prestige and Warm Glow. Journal of Public Economics 67: 169-284.

Jones, T. M., Thomas, T. E., Agle, B. R. \& Ehreth, J. 1990. Graduate Business Education and the Moral Development of MBA Students. Proceedings of the First Annual Meeting of the International Association for Business and Society. 43-53.

Kelley, H. H. \& Stahelski, A. J. 1970. Social Interaction Basis of Cooperators' and Competitors' Beliefs about Others. Journal of Personality and Social Psychology 16(1): 6691.

Kirchgässner, G. 1992. Towards a Theory of Low-Cost-Decisions. European Journal of Political Economy, 8: 305-320.

Laband, D.N. \& Beil, R.O. 1999. Are Economists More Selfish Than Other 'Social' Scientists? Public Choice, 100 (1-2): 85-101.

Marwell, G. \& Ames, R.E. 1981. Economists Free Ride, Does Anyone Else? Experiments on the Provision of Public Goods IV. Journal of Public Economics, 15: 295-310.

McCabe, D. L., Dukerich, J. M. \& Dutton, J. E. 1991. Context, Values and Moral Dilemmas: Comparing the Choices of Business and Law School Students. Journal of Business Ethics 10: 951-60. 
McCabe, D. L., Dukerich, J. M. \& Dutton, J. E. 1994. The Effects of Professional Education on Values and the Resolution of Ethical Dilemmas: Business School vs. Law School Students. Journal of Business Ethics 13: 693-700.

McClintock, C.G. 1978. Social Motivation - A Set of Propositions. Behavioral Science 17: 438-54.

Messick, D. M. \& McClintock, C.G. 1968. Motivational Bases of Choice in Experimental Games. Journal of Experimental Social Psychology 4: 1-25.

Nowell, C. \& Tinkler, S. 1994. The Influence of Gender in the Provision of a Public Good. Journal of Economic Behavior \& Organization 25: 25-36.

Olson, M. 1965. The Logic of Collective Action. Cambridge, Mass.: Harvard University Press. Ostrom, E. 1998. A Behavioral Approach to the Rational Choice Theory of Collective Action. Presidential Address, American Political Science Association 1997. American Political Science Review, 92 (1): 1-22.

Sally, D. 1995. Conversation and Cooperation in Social Dilemmas. A Meta-Analysis of Experiments from 1958 to 1992. Rationality and Society 7(1): 58-92.

Sawyer, J. 1966. The Altruism Scale: A Measure of Co-operative, Individualistic, and Competitive Interpersonal Orientation. The American Journal of Sociology, 71 (4): 407-416.

Schein, E. (1967). Organization Psychology. Englewood Cliffs, NJ: Prentice Hall.

Seguino, S., Stevens, T. \& Lutz, M.A. 1996. Gender and Cooperative Behavior: Economic Man Rides Alone. Feminist Economics, 2 (1): 1-21.

Stanley, T.D. \& Tran, U. 1998. Economics Students Need Not Be Greedy: Fairness and the Ultimatum Game. Journal of Socio-Economics, 27 (6): 657-664.

Thaler, R. H. 1985. Mental Accounting and Consumer Choice. Marketing Science, 4: 199-214.

Von Neumann, J. \& Morgenstern, O. 1947. Theory of Games and Economic Behavior.

Princeton: Princeton University Press.

Yezer, A.M., Goldfarb, R.S. \& Poppen, P.J. 1996. Does Studying Economics Discourage Cooperation? Watch What We Do, Not What We Say or How We Play. Journal of Economic Perspectives, 10 (1): 177-186. 
TABLE 1:

SUMMARY STATISTICS

\begin{tabular}{|c|c|c|c|c|}
\hline \multirow{2}{*}{\multicolumn{2}{|c|}{ Variables }} & \multicolumn{2}{|c|}{ Data set } & \multirow{2}{*}{$\frac{\text { Survey data }}{\text { Mean (s.d.) }}$} \\
\hline & & $\begin{array}{c}\text { Number of } \\
\text { Observations }\end{array}$ & $\begin{array}{l}\text { Percentage of the } \\
\text { student body }\end{array}$ & \\
\hline Total & & 180225 & & \\
\hline \multicolumn{2}{|c|}{ Business and Economics Students } & 18603 & 10.32 & $12.9 \%$ \\
\hline & Basic & 9247 & & \\
\hline & Freshmen & 1688 & & \\
\hline & Main stage & 7708 & & \\
\hline & Business Students & 5541 & & \\
\hline & Economics Students & 887 & & \\
\hline & Ph.D. & 1648 & & \\
\hline & Business Students & 1066 & & \\
\hline & Economics Students & 434 & & \\
\hline \multicolumn{2}{|c|}{ Non-Economists } & 161622 & 89.68 & $87.1 \%$ \\
\hline & Basic & 44664 & & \\
\hline & Freshmen & 11997 & & \\
\hline & Main stage & 89423 & & \\
\hline & Ph.D. & 27537 & & \\
\hline \multicolumn{2}{|c|}{ Pre-university economic knowledge } & 31480 & 17.47 & \\
\hline \multicolumn{2}{|c|}{ Age, Mean (s.d.) } & $27.78(8.05)$ & & $26.657(5.59)$ \\
\hline & Aged below 26 & 86385 & 47.93 & \\
\hline & Aged 26-30 & 49453 & 27.44 & \\
\hline & Aged 31-35 & 22847 & 12.68 & \\
\hline & Aged 36-40 & 11024 & 6.12 & \\
\hline & Aged above 40 & 10516 & 5.83 & \\
\hline \multirow[t]{2}{*}{ Gender } & Women & 91062 & 50.53 & $47.5 \%$ \\
\hline & Men & 89163 & 49.47 & $52.5 \%$ \\
\hline \multirow[t]{2}{*}{ Nationality } & Foreigner & 21092 & 11.70 & \\
\hline & & 159133 & 88.30 & \\
\hline \multicolumn{2}{|c|}{ Number of semesters, Mean (s.d.) } & $10.47(8.21)$ & & $6.94(5.07)$ \\
\hline \multicolumn{2}{|c|}{ Time dummy 1 (winter semester 1998/99) } & 19507 & & \\
\hline \multicolumn{2}{|c|}{ Time dummy 2 (summer semester 1999) } & 18231 & & \\
\hline \multicolumn{2}{|c|}{ Time dummy 3 (winter semester 1999/00) } & 20060 & & \\
\hline \multicolumn{2}{|c|}{ Time dummy 4 (summer semester 2000) } & 18650 & & \\
\hline \multicolumn{2}{|c|}{ Time dummy 5 (winter semester 2000/01) } & 20335 & & \\
\hline \multicolumn{2}{|c|}{ Time dummy 6 (summer semester 2001) } & 19075 & & \\
\hline \multicolumn{2}{|c|}{ Time dummy 7 (winter semester 2001/02) } & 21004 & & \\
\hline \multicolumn{5}{|c|}{ Time dummy 8 (summer semester 2002) } \\
\hline \multicolumn{5}{|c|}{ Time dummy 9 (winter semester 2002/03) } \\
\hline \multicolumn{2}{|c|}{ Income $(\mathbf{C H F})$} & & & $1372(1924)$ \\
\hline \multicolumn{2}{|c|}{ Percentage earning their own living } & & & $57.6(34.7)$ \\
\hline \multicolumn{2}{|c|}{ Parents paying } & & & $45.4 \%$ \\
\hline
\end{tabular}

Data source: Compiled from data provided by the accounting department of the University of Zurich. 


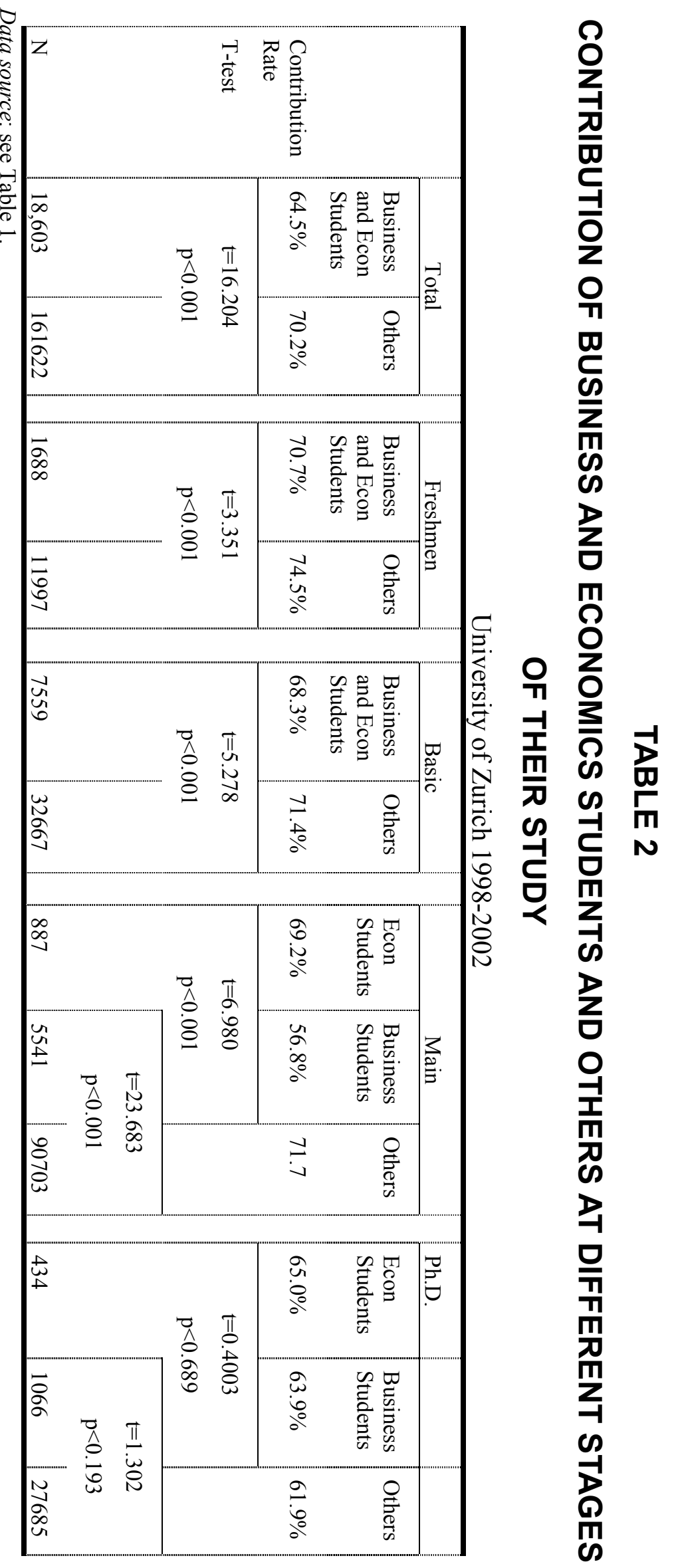


TABLE 3:

CONTRIBUTION OF ECONOMISTS AND NON-ECONOMISTS IN THE FIRST

\section{SEMESTER}

University of Zurich 1998-2002,

Dichotomous dependent variable: 'Contribution to at least one fund' $=1$, Probit estimates

\begin{tabular}{|c|c|c|c|}
\hline Variable & Coefficient & Z-value & Marginal effect \\
\hline $\begin{array}{l}\text { Business and Econ Students }(1=\text { Business } \\
\text { and Econ Students) }\end{array}$ & $-0.133 * *$ & -3.67 & $-4.4 \%$ \\
\hline Pre-university knowledge & $-0.089 * *$ & -2.97 & $-2.9 \%$ \\
\hline \multicolumn{4}{|l|}{ Control variables } \\
\hline Gender $($ female $=1)$ & $-0.138 * *$ & -5.72 & $-4.4 \%$ \\
\hline Nationality (foreigner $=1$ ) & -0.003 & -0.07 & $-0.1 \%$ \\
\hline Aged below 26 & \multicolumn{3}{|c|}{ Reference group } \\
\hline Aged 26-30 & 0.028 & 0.54 & $0.9 \%$ \\
\hline Aged 31-35 & 0.115 & 1.39 & $3.6 \%$ \\
\hline Aged 36-40 & 0.213 & 1.80 & $6.4 \%$ \\
\hline Aged above 40 & $0.349^{*}$ & 2.61 & $9.9 \%$ \\
\hline Time dummy 1 (winter semester 1998/99) & \multicolumn{3}{|c|}{ Reference group } \\
\hline Time dummy 2 & 0.172 & 1.53 & $5.2 \%$ \\
\hline Time dummy 3 & $0.382 * *$ & 10.14 & $11.3 \%$ \\
\hline Time dummy 4 & 0.164 & 1.45 & $5.0 \%$ \\
\hline Time dummy 5 & $0.396 * *$ & 10.38 & $11.6 \%$ \\
\hline Time dummy 6 & $0.374 * *$ & 2.93 & $10.5 \%$ \\
\hline Time dummy 7 & $0.331 * *$ & 8.97 & $9.9 \%$ \\
\hline Time dummy 8 & $0.54 * *$ & 4.27 & $14.1 \%$ \\
\hline Time dummy 9 (winter semester 2002/03) & $0.420 * *$ & 11.49 & $12.4 \%$ \\
\hline Constant & $0.445 * *$ & 14.48 & \\
\hline $\mathrm{N}$ & \multicolumn{3}{|l|}{13,685} \\
\hline Log Likelihood & \multicolumn{3}{|l|}{-7719.7007} \\
\hline
\end{tabular}

Notes: Reference group consists of 'non-economists', 'without pre-university economic knowledge', 'aged below 26', 'male', 'Swiss', ' winter semester 1998/99'.

Level of significance: $* 0.01<\mathrm{p}<0.05, * * \mathrm{p}<0.01$

Data source: see Table 1. 
TABLE 4:

CONTRIBUTION OF BUSINESS AND ECON STUDENTS IN THE FIRST SEMESTER

UNIVERSITY OF ZURICH 1998-2002

\begin{tabular}{|c|c|c|c|c|c|c|}
\hline \multirow{5}{*}{$\begin{array}{l}\text { To at least one Fund } \\
\text { T-test of differences }\end{array}$} & \multicolumn{3}{|c|}{ Freshmen } & \multicolumn{3}{|c|}{ Basic study } \\
\hline & $\begin{array}{c}\text { Econ } \\
\text { students }\end{array}$ & $\begin{array}{l}\text { Business } \\
\text { students }\end{array}$ & $\begin{array}{l}\text { All } \\
\text { Others }\end{array}$ & $\begin{array}{c}\text { Econ } \\
\text { students }\end{array}$ & $\begin{array}{l}\text { Business } \\
\text { students }\end{array}$ & Others \\
\hline & $76.9 \%$ & $60.1 \%$ & \multirow[t]{2}{*}{$74.2 \%$} & $73.9 \%$ & $65.3 \%$ & \multirow[t]{2}{*}{$71.1 \%$} \\
\hline & \multicolumn{2}{|c|}{$\begin{array}{l}\mathrm{t}=1.999 \\
\mathrm{p}<0.047\end{array}$} & & \multicolumn{2}{|c|}{$\begin{array}{l}\mathrm{t}=3.416 \\
\mathrm{p}<0.001\end{array}$} & \\
\hline & \multicolumn{3}{|c|}{$\begin{array}{l}\mathrm{t}=4.557 \\
\mathrm{p}<0.001\end{array}$} & & \multicolumn{2}{|c|}{$\begin{array}{l}\mathrm{t}=5.441 \\
\mathrm{p}<0.001\end{array}$} \\
\hline $\mathrm{N}$ & 39 & 203 & 13438 & 418 & 1914 & 37905 \\
\hline
\end{tabular}


TABLE 5:

CONTRIBUTION OF BUSINESS STUDENTS AND ECONOMICS STUDENTS

University of Zurich 1998-2002

Dichotomous dependent variable: 'Contribution to at least one fund' $=1$

Model I

Probit estimate

Variable

Business and economics students

Stages of study

Main stage

Main stage*Business Students

Main stage*Economics Students

Ph.D.

Ph.D.*Business Students

Ph.D.*Economics Students

$\begin{array}{ll}0.116^{* *} & 13.12 \\ -0.228^{* *} & -10.26 \\ 0.091^{*} & 1.95\end{array}$

$-0.021$

$0.177 * *$

$0.164^{*}$

$-1.64$

4.17

2.56
$-12.37$

$4.0 \%$

$-8.3 \%$

$3.1 \%$

$-0.7 \%$

$5.9 \%$

$5.4 \%$

$-3.7 \%$

Pre-university economic knowledge

\section{Control variables}

\begin{tabular}{|c|c|c|c|c|c|}
\hline Age & $0.023 * *$ & 30.88 & $7.9 \%$ & 0.035 & 0.24 \\
\hline Age squared & $-0.000 * *$ & -20.42 & $-0.0 \%$ & -0.000 & -0.12 \\
\hline Gender $($ female $=1)$ & $-0.039 * *$ & -6.05 & $-1.3 \%$ & & \\
\hline Nationality (foreigner $=1$ ) & $-0.134 * *$ & -13.85 & $-4.8 \%$ & & \\
\hline Number of semesters & $-0.048 * *$ & -38.69 & $-1.7 \%$ & $-0.099 * *$ & -3.58 \\
\hline (Number of semesters) squared & $0.001 * *$ & 24.08 & $0 \%$ & $0.001 *$ & 2.29 \\
\hline Time dummy 2 & $0.081 * *$ & 6.01 & $2.8 \%$ & $0.280 *$ & 2.10 \\
\hline Time dummy 3 & $0.141 * *$ & 10.74 & $4.8 \%$ & $0.403 * *$ & 2.90 \\
\hline Time dummy 4 & $0.140 * *$ & 10.46 & $4.7 \%$ & 0.371 & 1.40 \\
\hline Time dummy 5 & $0.178 * *$ & 13.56 & $6.0 \%$ & 0.420 & 1.55 \\
\hline Time dummy 6 & $0.163 * *$ & 12.18 & $5.4 \%$ & 0.365 & 0.92 \\
\hline Time dummy 7 & $0.186^{* *}$ & 14.21 & $6.2 \%$ & 0.367 & 0.90 \\
\hline Time dummy 8 & $0.327 * *$ & 24.34 & $10.5 \%$ & 0.869 & 1.63 \\
\hline Time dummy 9 & $0.199 * *$ & 15.57 & $6.6 \%$ & 0.372 & 0.69 \\
\hline onstant & $0.148 * *$ & 7.70 & & & \\
\hline gg Likelihood & $\begin{array}{c}180,225 \\
-108372.03\end{array}$ & & & $\begin{array}{r}74,98 \\
-27986 . \\
\left(\mathrm{LR} \mathrm{chi}^{2}\right)\end{array}$ & \\
\hline
\end{tabular}

Notes: Reference group consists of 'non-economists', 'basic study', 'without pre-university economic knowledge', 'aged below 26', 'male', 'Swiss', 'semester 1998/99'.

Level of significance: $* 0.01<\mathrm{p}<0.05, * * \mathrm{p}<0.01$

Data source: see Table 1.
Model II

Conditional fixed effect logit Coefficient Z-value 
TABLE 6:

\section{INCOME FACTORS AFFECTING GIVING BEHAVIOR}

University of Zurich 2000

Dichotomous dependent variable: 'Contribution to at least one fund' $=1$

Probit estimates

\begin{tabular}{|c|c|c|c|c|c|c|}
\hline \multirow[b]{2}{*}{ Variable } & \multicolumn{3}{|c|}{ Model I } & \multicolumn{3}{|c|}{ Model II } \\
\hline & Coefficient & Z-value & Marginal effect & Coefficient & Z-value & Marginal effect \\
\hline Business and Economics Students & 0.152 & 1.281 & $4.9 \%$ & 0.036 & 0.295 & $1.0 \%$ \\
\hline \multicolumn{7}{|l|}{ Stages of study } \\
\hline Main stage & 0.045 & 0.603 & $1.5 \%$ & 0.050 & 0.649 & $1.4 \%$ \\
\hline Main stage*Business Students & $-0.427 *$ & -2.523 & $-13.8 \%$ & $-0.372 *$ & -2.146 & $-10.0 \%$ \\
\hline Main stage*Economics Students & -0.245 & -0.91 & $-7.9 \%$ & -0.362 & -1.347 & $-9.8 \%$ \\
\hline 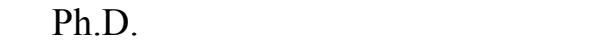 & 0.011 & 0.103 & $0.4 \%$ & 0.018 & 0.155 & $0.5 \%$ \\
\hline Ph.D.*Business Students & 0.250 & 0.481 & $8.1 \%$ & 0.016 & 0.031 & $0.4 \%$ \\
\hline Ph.D.*Economics Students & 0.378 & 0.562 & $12.2 \%$ & 0.215 & 0.327 & $5.8 \%$ \\
\hline \multicolumn{7}{|l|}{ Income situation } \\
\hline $\log ($ income) & & & & $0.207 * *$ & 4.704 & $5.6 \%$ \\
\hline Contribution (\%) towards own upkeep & & & & $-0.004 * *$ & -3.135 & $-0.1 \%$ \\
\hline Parents paying fees & & & & -0.123 & -1.645 & $-3.5 \%$ \\
\hline \multicolumn{7}{|l|}{ Control variables } \\
\hline Age & $0.014 *$ & 2.153 & $0.4 \%$ & 0.006 & 0.754 & $0.2 \%$ \\
\hline Sex $($ female $=1)$ & 0.056 & 0.972 & $1.8 \%$ & $0.138 *$ & 2.260 & $3.7 \%$ \\
\hline Number of semesters & $-0.019 * *$ & -2.83 & $-0.6 \%$ & -0.013 & -1.778 & $-0.3 \%$ \\
\hline Constant & $0.365^{*}$ & 2.253 & & -0.418 & 1.300 & \\
\hline $\mathrm{N}$ & 2321 & & & 2425 & & \\
\hline Log likelihood & -1322.2735 & & & -1177.2832 & & \\
\hline
\end{tabular}

Notes: Reference group consists of 'non-economists', 'basic study', 'males', who 'pay their fees themselves'.

Level of significance: $* 0.01<\mathrm{p}<0.05, * * \mathrm{p}<0.01$

Data source: Own survey carried out at the University of Zurich 2000. 


\section{TABLE 7}

\section{PERCEIVED EFFICIENCY OF THE TWO FUNDS}

\begin{tabular}{|c|c|c|c|c|c|}
\hline \multicolumn{6}{|c|}{$\begin{array}{c}\text { 'How do you evaluate the effectiveness of the funds?' } \\
\text { (On a scale from } 8=\text { 'good' to } 1=\text { 'bad') }\end{array}$} \\
\hline & \multicolumn{2}{|c|}{$\begin{array}{c}\text { Business and } \\
\text { Economics Students }\end{array}$} & \multicolumn{2}{|c|}{ Other Students } & \multirow{2}{*}{$\begin{array}{c}\begin{array}{c}\text { t-test of } \\
\text { differences }\end{array} \\
\mathrm{t} \text {-value } \\
(\mathrm{P}>\mathrm{t})\end{array}$} \\
\hline & Mean & $\begin{array}{l}\text { s.d. } \\
(\mathrm{N})\end{array}$ & Mean & $\begin{array}{l}\text { s.d. } \\
(\mathrm{N})\end{array}$ & \\
\hline Basic Study & 4.96 & $\begin{array}{c}1.65 \\
(115)\end{array}$ & 5.31 & $\begin{array}{l}1.62 \\
(622)\end{array}$ & $\begin{array}{c}2.15 \\
(0.05)\end{array}$ \\
\hline Main Study & 4.82 & $\begin{array}{c}1.83 \\
(123)\end{array}$ & 5.31 & $\begin{array}{c}1.80 \\
(877)\end{array}$ & $\begin{array}{l}2.79 \\
(0.01)\end{array}$ \\
\hline Ph. D. Study & 4.56 & $\begin{array}{l}2.34 \\
(16)\end{array}$ & 4.96 & $\begin{array}{l}2.03 \\
(194)\end{array}$ & $\begin{array}{c}0.74 \\
(0.23)\end{array}$ \\
\hline Total & 4.87 & $\begin{array}{l}1.78 \\
(254)\end{array}$ & 5.27 & $\begin{array}{c}1.77 \\
(1693)\end{array}$ & $\begin{array}{c}3.37 \\
(0.01)\end{array}$ \\
\hline
\end{tabular}

Notes: Without the ,No idea' answers.

Data source: Own survey carried out at the University of Zurich 2000. 
TABLE A.1:

VARIOUS MEASUREMENTS OF 'INDOCTRINATION'

University of Zurich 1998-2002

Dichotomous dependent variable: 'Contribution to at least one fund' $=1$

\begin{tabular}{|l|l|l|l|l|}
\hline Variables & III & IV & V & VI \\
\hline & Probit & Fixed-Effect & Probit & Fixed-Effect \\
\hline Business and Econ students & $\begin{array}{l}-0.105^{* *} \\
(0.017)\end{array}$ & & $\begin{array}{l}-0.099^{* *} \\
(0.013)\end{array}$ & \\
\hline Number of Economics semesters & $\begin{array}{l}-0.005^{* *} \\
(0.001)\end{array}$ & $\begin{array}{l}-0.000 \\
(0.012)\end{array}$ & & \\
\hline Number of Business semesters & & & $-0.011^{* *}$ & -0.007 \\
& & & $(0.001)$ & $(0.009)$ \\
\hline Number of Economics semesters & & & $0.005^{*}$ & -0.017 \\
& & & $(0.002)$ & $(0.022)$ \\
\hline Main stage & $0.121^{* *}$ & $0.234^{* *}$ & $0.125^{* *}$ & 0.151 \\
& $(0.009)$ & $(0.036)$ & $(0.009)$ & $(0.080)$ \\
\hline Ph.D. stage & 0.006 & 0.145 & 0.008 & 0.000 \\
& $(0.013)$ & $(0.080)$ & $(0.013)$ & $(0.003)$ \\
\hline Pre-university economic & -0.101 & & $-0.101^{* *}$ & \\
knowledge & $(0.008)$ & & $(0.008)$ & \\
\hline Control variables & Yes & Yes & Yes & Yes \\
\hline N & 180,225 & & 180,225 & 74,982 \\
\hline Log likelihood & -108422.16 & & -108393.66 & -27992.061 \\
\hline
\end{tabular}

Notes: Standard errors in parentheses. Reference group consists of 'non-economists', 'basic study', 'without pre-university economic knowledge', 'aged below 26', 'male', 'Swiss', 'semester 1998/99'.

Level of significance: $* 0.01<\mathrm{p}<0.05, * * \mathrm{p}<0.01$

Data source: see Table 1. 
${ }^{\mathrm{i}}$ See Ledyard (1995) for a survey on contribution to public goods in laboratory experiments, and Ostrom (1998) for an overview about contribution to a broader range of common goods.

ii There are many studies in experimental economics which detect different 'types' in the population. See, e.g., Andreoni and Vesterlund (2001) and Charness and Rabin (2002). iii The on-line questionnaire is reproduced at http://www.iew.unizh.ch/grp/frey/fragebogen.htm.

${ }^{\text {iv }}$ Various studies found that women tend to behave more pro-socially than men. See, e.g., Eckel and Grossman (1997), Nowell and Tinkler (1994) and Andreoni and Vesterlund (2001).

${ }^{\mathrm{v}}$ In the literature, a positive effect of age on donating is explained either by effects of wealth or income, which correlates with age or with some sort of cohort effect or lifecycle effect (Clotfelter, 1997). The discussion of these effects would, however, go beyond the scope of this paper.

${ }^{v i}$ For the contribution rate of student of other subjects, see Frey and Meier (2003a).

vii In order to make the table not too confusing, we didn't show the control for freshmen. The inclusion of the variable would, however, not change the effect of being a business or economics student when contributing. 